\title{
Unlock Day Expiration and Mandatory IPOs Lock up Among ACE Firms in Malaysia
}

\author{
Syamsyul Samsudin ${ }^{1}$, Nik Nur Shafika Mustafa ${ }^{1}$, Nor Haliza Hamzah ${ }^{1} \&$ Che Khalilah Mahmood ${ }^{1}$ \\ ${ }^{1}$ Faculty of Business and Management, Universiti Teknologi MARA, Segamat, Malaysia \\ Correspondence: Syamsyul Samsudin, Faculty of Business and Management, Universiti Teknologi MARA, Segamat, \\ Malaysia. E-mail: syam681@uitm.edu.my
}

Received: May 12, 2020

doi:10.5430/ijfr.v11n3p131
Accepted: June 20, 2020

Online Published: June 29, 2020

URL: https://doi.org/10.5430/ijfr.v11n3p131

\begin{abstract}
This research studied the role of lockup in assessing price and volume of IPOs during the expiration of lockup in Malaysian market. The reaction of price is measured by the abnormal return while the reaction of volume is measured by the abnormal volume. The companies were selected from the years 2010 to 2018 and only companies that were still listed in Bursa Malaysia were chosen. The time frame of the study was 30 days before and 30 days after the expiration date of lock up provision. The results may show for these circumstances of i) the volume will remain and the price will decrease; ii) volume will be decreased and price will be decreased too and iii) promoters retain percentage of shares during expiration date. For situation number i), it might show the sign of a quite good quality of performance of IPOs in stock market. Evidently, the second circumstance shows decrease in price and volume of IPOs after expiration date. The scenario actually leads by demand and supply of stock. Another important evidence which supports the insignificant result is promoters retain percentage of shares during expiration date. The amounts that should be released by the companies are not offered to the market during that time. By looking at the Signaling Theory, insiders of IPOs firms who are previously restricted from selling their holdings have the first chance to sell large propositions of their shares. Investors will know the dates of IPO lockup expiration and numbers of shares by looking at the prospectus. Due to the scenario, the price and volume of IPOs will be reacting during expiration date based on this theory. It is hoped that this study will help investors or any Malaysian market participation especially in the IPOs market to notice the situation in Malaysian market regarding the lock up provision.
\end{abstract}

Keywords: initial public offering, lock up provision, moratorium, underprice, volume

\section{Background of the Study}

Most of the companies that are involved in IPOs have the intention to raise their capital, and increase the public awareness about the company's existence which may lead to new customers and opportunities. Malaysia is one of the countries in the world that has significant changes in the number of IPOs each year which proves active participation and interest from firms in Malaysia to do IPOs. IPO is an attractive investment to investors even though it can be considered as a risky investment because this type of shares does not have any past history regarding its performance. Besides, companies that issue IPOs are mostly young or developing companies which can cause speculation about the performance of the IPOs in the futures. Mostly, IPOs will face under-pricing which means the shares are sold below its market value because of concerns from investors regarding the liquidity and uncertainty of the shares. These concerns occur due to no historical performance of the shares since they are newly issued shares. If the shares are very unpredictable that they cause uncertainty, and if liquidity of the shares is less, the shares could be more under-priced than its market value. However, this could be a normal situation that happens to all IPOs because it is the first time for the shares to be traded to public. Stock performance can be measured in many ways depending on the method preferred by the investor or analyst. Jensen, Treynor and Sharpe's method is usually used to measure portfolio performance. IPO lock up provision which is also known as moratorium provision is a restriction to companies that sell shares for the first time from selling all of their shares for a specific period. Different from other countries, Malaysia has a fixed lock-up length of six months that was set by the Securities Commission of Malaysia which causes IPO companies to being unable to choose the length of lock-up that they desire. This provision can be explained from Policies and Guidelines on Issue/Offer of Securities that was published in 1995. Due to the rules and 
regulations by Securities Commission of Malaysia, any companies that seek for listing in the Bursa Malaysia are required to do lock-up for a six-month period. Thus, they do not have any choice to set a period that they desire. Previous researchers have conducted a lot of studies to see the reaction of IPOs towards the expiration date of the lock up provision. Goergen, Mazouz and Yin (2010) who conducted a research to see the reaction of price, volume and bid ask spread in Hong Kong market found that there are significant reaction for volume and bid ask spread towards the expiry date of lock up provision. The study also proved that price has shown no reaction on the expiration date of the lock up. Thus, it is interesting to see the IPOs reaction in Malaysia towards the lock up date since the period is fixed for six months unlike the other countries. This research aims to examine the reaction of IPO's price and volume upon the expiration of the lock-up period in Malaysian context.

\section{Previous Studies}

\subsection{IPO Performance}

Many researches have been conducted to study the performance of initial public offering in Malaysia or other countries. Most of the researches focused on the under-pricing of IPO or initial return, its effect, and determinants. Boonchuaymetta and Chuanrommanee (2013) carried out a study by using data that comprised 153 listed companies from the years 2001 until 2011 to study the effect of six major IPO elements in Thailand (which include the reputation of underwriter, the concentration of ownership, book-building, the allocation of IPO, lockup period length and investor interest) on the under-pricing. Their findings suggest that only IPO allocation and the lockup length can determine the under-pricing in Thailand. Another research conducted by Su, D. (2004) studied the leverage informational role and insider ownership signalling role to the IPO under-pricing. The data in this study consisted of 348 non-financial firm-commitment domestic IPOs in the period between 1 January 1994 and 31 December 1999. The study found that the under-pricing tends to be larger when the pre-IPO leverage is larger. The IPO under-pricing is also found to be higher when there is presence of lottery mechanism in shares allocation. Firm quality can also be signalled by the insider ownership together with IPO under-pricing.

There were also some studies done to examine the IPO under-pricing in Malaysia. By using 385 IPO firms that sought for listing in Bursa Malaysia for the years 1999 to 2008, Yatim, P. (2011) studied the relationship between board structures and the under-pricing of IPO. The result showed that there is significant positive relationship between dual leadership, reputation of board and under-pricing of IPO in Malaysia. Besides that, there are no significant links to under-pricing by other board variables such as size and independence. Rahim and Yong (2010) further examined whether the Shari'a-compliant status would alter the pattern of initial return of Malaysian IPOs. Their findings suggested that the status would not alter the patterns of IPOs initial return in Malaysia significantly. Sapian, Rahim and Yong (2013) used sample data from June 2003 to December 2008 which consisted of 191 initial public offerings that were listed on Bursa Malaysia to study the effects of under-pricing on the aftermarket liquidity. They stated that generally, there is significant and direct impact of under-pricing on the IPO aftermarket liquidity. IPOs that have a larger offer and issued by firms with more volatile stocks return tend to be more liquid. Moreover, it was also found that certain events in the economy and market had lessened the liquidity in 2004, 2005 and 2008 (US sub-prime crisis) to be lower than the liquidity in 2003.

Another research that was done to study the IPO performance in Malaysia was conducted by Yong, O. (2011) to see how the investor demand issues and size effect can explain the IPOs under-pricing phenomenon in Malaysia, and how it affected the IPOs immediate post-listing behaviour. This study used sample data of 277 Malaysian IPOs from January 2004 to December 2010 and showed that there was higher demand of initial return from the uninformed investors. Besides that, IPOs listed on the ACE market had a higher initial return compare to IPOs that were listed on the Main Market. This shows that size is an important factor that can affect the under-pricing in Malaysia. Next, Younesi, Ardekani and Hashemijoo (2012) used 66 selected IPOs from Bursa Malaysia for years 2007 to 2010 to study the performance of Malaysian IPOs during the period. The study showed interesting findings where age of firms, size of firms, total offered unit, price of offering and the movement of KLCI index have no significant relationship with IPO initial return.

\subsection{Lockup Provision}

There were also some researches done to study the lockup provision in Malaysia and other countries. However, most of these researches were done with sample data from foreign countries due to the attractiveness of lockup provision in other countries compare to Malaysia. Hussin (2005) carried out a study to determine the effect of owner participation and lockup on IPO under-pricing. This study used a sample data from Bursa Malaysia from the years 1996 to 2000. The lockup variable in this study was represented by the lockup ratio and the finding showed that both owner participation and lockup have a significant impact on under-pricing of IPO. Another research was done by 
Rashid, R. M., Abdul-Rahim, R., \& Yong, O. (2014) with sample of data from 2000 to 2012 taken from Bursa Malaysia to find out if initial return of IPO can be affected by the lockup ratio and lockup period. In contrast with Hussin, W. N. (January, 2005), their finding suggested that lockup ratio will not have any effect on initial return but lockup period has a significant impact on initial return of IPO. A study by Che-Yahya, N., Abdul-Rahim, R., \& Mohd-Rashid, R. (2015) to learn how initial return and flipping activity can be affected by the lockup provisions used a sample data which consisted of 383 Malaysian IPOs listed from January 2000 to December 2013. The findings suggested that lockup provision (lockup ratio and lockup period) has a significant negative relationship to flipping activity and indicates that lockup provision is more suitable to be used as commitment and controlling tool instead of a quality signal tool.

Ahmad and Jelic (2014) did a study to find out the role of lockup agreements on the survival of UK IPOs. The sample data used comprised 580 UK IPOs that were taken from 1990 to 2011 and they found that the survival of IPO firms can be improved by increasing the length of lockup period. One other research was done by using data from U.S.A. for the years 1990 until 1994 and 2001 until 2005 to identify the impact and uses of lockup period as signal, and then compared with the other signals of quality. This research, conducted by Arthurs, J. D., Busenitz, L. W., Hoskisson, R. E., \& Johnson, R. A. (2009) found that lockup period can be used as a signal of quality when venture capital backing and prestigious underwriter are not available. Brau, Carter, Christophe and Key (2004) studied the effects of IPO lockup features on the share price and market activity by using data from America for the years 1988 to 1998. This study showed that there are important implications to the price and market activity as the lockup provision expired. Goergen et al. (2010) identified the volume, price and bid-ask spread reactions as lock-in expired in Hong Kong IPOs. The data were collected from the years May 1999 till December 2005 and they found that there is no effect on the price upon the lock-in expiration in the Hong Kong IPO market and bid-ask spread also increases around the lock-in expiry.

\section{Research Methodology}

\subsection{Population and Sample}

The sample used in this research to test the reaction of price consisted of 22 samples of initial public offering companies while 21 samples of initial public companies. All of the companies are listed in Bursa Malaysia and taken only from the ACE Market. The companies were selected from the years 2010 to 2018. Time series data were used on daily basis which consisted of 30 days before and after the expiration of the lock up provision period.

\subsection{Event Study}

This research used event study which is a method to assess the impact of IPOs before and after expiration of lockup period. Mackinlay (1997) designed the time frame for an event study for accounting and finance, management, economics, marketing, information technology, law and political science. In this study, there were eight data sets with scenario which were 7 days, 14 days, 21 days, 30 days before expiration and 7 days, 14 days, 21 days, 30 days after expiration. Figure 1 below illustrates the time frame for this study.

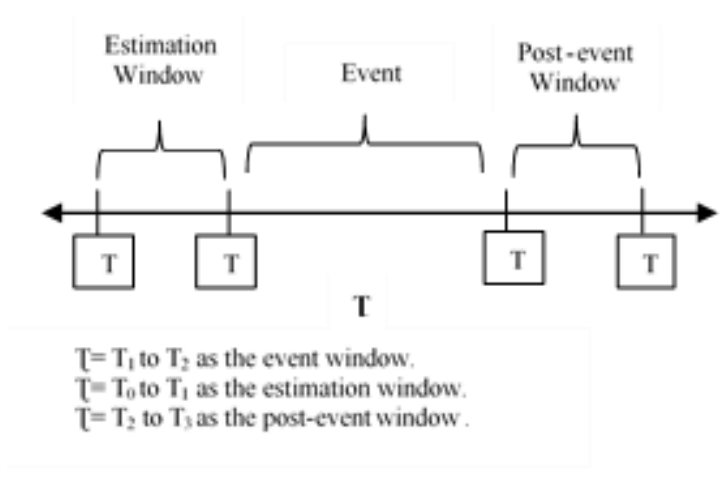

Figure 1. Event study diagram

The period of the event study can be divided into 4 sub-periods which are period 1-7 days, period 2-14 days, period 3-21 days and period 4-30 days. Figure 2 below illustrates the sub-periods. 


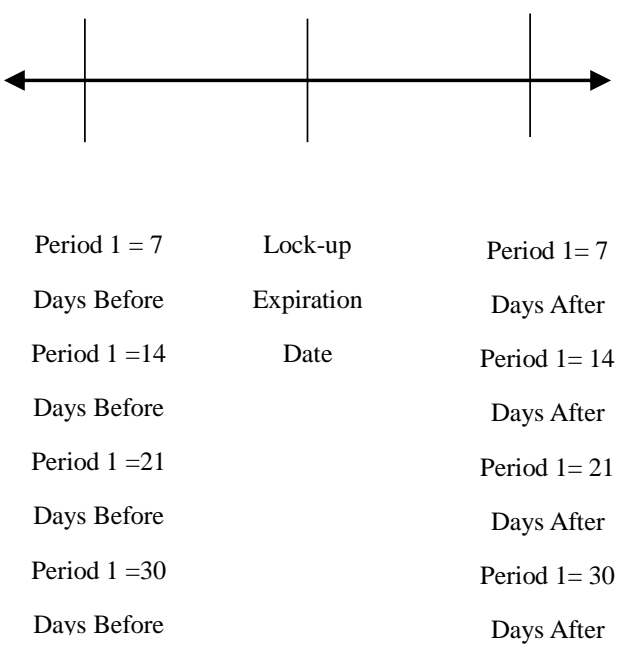

Figure 2. Sub period event study

3.3 Hypothesis

i. Price

- Period 1: Abnormal returns on IPOs react on lockup date for 7 days before expiration.

- Period 2: Abnormal return on IPOs reacts on lockup date for 14 days before expiration.

- Period 3: Abnormal return on IPOs reacts on lockup date for 21 days before expiration.

- Period 4: Abnormal return on IPOs reacts on lockup date for 30 days before expiration.

ii. Volume

- Period 1: Abnormal volumes on IPOs react on lockup date for 7 days before expiration.

- Period 2: Abnormal volumes on IPOs react on lockup date for 14 days before expiration.

- Period 3: Abnormal volumes on IPOs react on lockup date for 21 days before expiration.

- Period 4: Abnormal volumes on IPOs react on lockup date for 30 days before expiration.

\subsection{Statistical Tools and Instruments}

Market model assumes that there is stable linear model relationship (beta) between stock market return and market return, and stock volume changes and market volume changes. Daily abnormal return security and daily abnormal volume from 7, 14, 21, and 30 days before and after events have been computed as follows:

\begin{tabular}{|c|c|c|}
\hline Step 1 & $\begin{array}{l}\text { Return for each companies } \\
\text { and market were calculated } \\
\text { from day }-30 \text { until day } 30 \\
\text { using the formula: }\end{array}$ & $\begin{array}{l}\quad \text { Rit }=\left(\mathbf{P i t}_{\mathbf{1}}-\mathbf{P i t}_{\mathbf{0}}\right) / \mathbf{P i t}_{\mathbf{0}} \\
\text { where; } \\
\text { Rit } \quad: \text { Return of firm } i \text { at day } t \\
\text { Pit }_{1}: \text { New price of shares of firm } i \\
\text { Pit }_{0} \quad: \text { Old price of shares of firm } i \\
\quad \text { and } \\
\qquad \\
\text { Rmt }=\left(\mathbf{P m t}_{\mathbf{1}}-\mathbf{P m t}_{\mathbf{0}}\right) / \mathbf{P m t}_{\mathbf{0}} \\
\text { where; } \\
\text { Rmt } \quad \text { Return of market at day } t \\
\text { Pmt }_{1}: \text { New price of shares of market at day } t \\
\text { Pmt }_{0}: \text { Old price of shares of market at day } t\end{array}$ \\
\hline
\end{tabular}




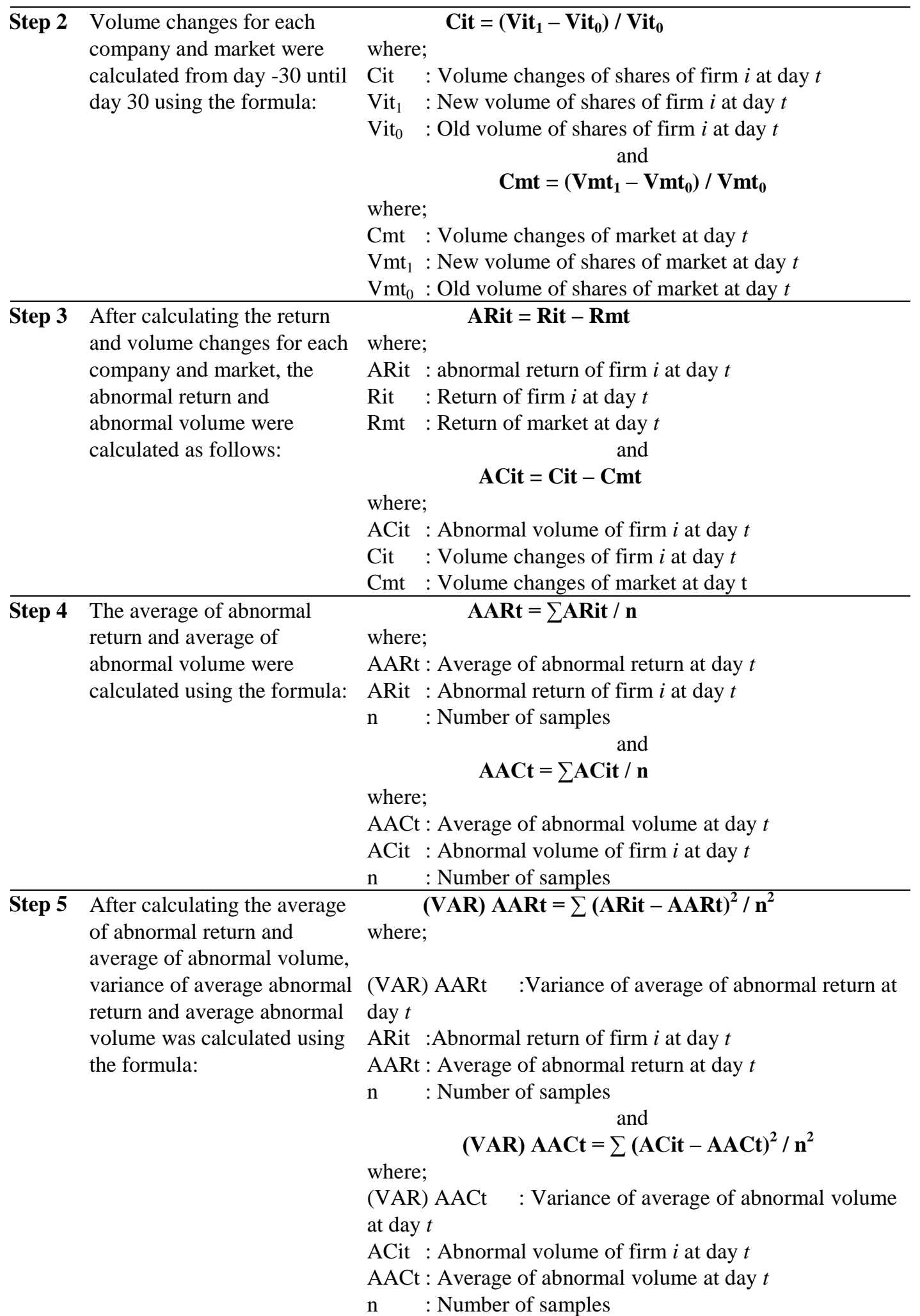

Step 6 Standard deviation of average abnormal return and average abnormal volume then were calculated by using the following formula:

\section{(s.d.) $\mathbf{r}=\sqrt{ }[($ VAR)AARt $]$}

where;

(s.d.) $\mathrm{r} \quad$ : Standard deviation of average abnormal return at day $t$ (VAR)AARt: Variance of average abnormal return at day $t$ and 


\begin{tabular}{|c|c|c|}
\hline & (s.d.) $c=\sqrt{ }[(\mathrm{VAR}) \mathrm{AACt}]$ \\
\hline & & $\begin{array}{l}\text { where; } \\
\text { (s.d.) c : Standard deviation of average abnormal } \\
\text { volume at day } t \\
\text { (VAR)AACt: Variance of average abnormal volume at day } \\
t\end{array}$ \\
\hline Step 7 & $\begin{array}{l}\text { After obtaining the value of } \\
\text { each average abnormal return } \\
\text { and average abnormal } \\
\text { volume at each day, and } \\
\text { standard deviation for both, } \\
\text { the t-value was calculated } \\
\text { using the formula: }\end{array}$ & $\begin{array}{l}\text { t-value }=\text { AARt } /(\text { s.d. }) \mathbf{r} \\
\text { where; } \\
\text { t-value } \quad: \text { value for t-test } \\
\text { AARt : Average of abnormal return at day } t \\
\text { (s.d.) r } \quad: \text { Standard deviation of average abnormal return } \\
\text { at day } t \\
\quad \text { and } \\
\text { t-value }=\text { AACt } / \text { (s.d.) c } \\
\text { where; } \\
\text { t-value } \quad: \text { value for t-test } \\
\text { AACt } \quad: \text { Average abnormal volume at day } t \\
\text { (s.d.) c } \quad: \text { Standard deviation of average abnormal } \\
\text { volume at day } t\end{array}$ \\
\hline
\end{tabular}

Step 8 After calculating the $\mathrm{t}$-value for the average abnormal return and average abnormal volume, the value was compared to the t-table at $5 \%$ significant level.

\section{Data Analysis and Findings}

4.1 Findings on Reactions Abnormal Return 7, 14, 21 and 30 Days Before and After Lock up Date

Table 1. Reactions abnormal return 7, 14, 21 and 30 days before and after lock up date

\begin{tabular}{cccc}
\hline Sub period & AARt & S.D. & T-VALUE \\
\hline \multicolumn{2}{c}{ Before Lock-up Date } & & \\
\hline$(-7,0)$ & 0.008812 & 0.005991 & 1.470850 \\
\hline$(-14,0)$ & 0.004471 & 0.005944 & 0.752182 \\
\hline$(-21,0)$ & -0.003533 & 0.006310 & -0.559913 \\
\hline$(-30,0)$ & -0.001518 & 0.005555 & -0.27328 \\
\hline After Lock-up Date & & & \\
\hline$(+7,0)$ & 0.009181 & -0.006850 & -0.746136 \\
\hline$(+14,0)$ & 0.008033 & 0.005970 & 0.743191 \\
\hline$(+21,0)$ & 0.006870 & -0.001323 & -0.192581 \\
\hline$(+30,0)$ & 0.0071107 & -0.0024226 & -0.3407008 \\
\hline
\end{tabular}

Table 1 shows the result of the study for the first period which is 7 days before and 7 days after the lock up date expiration. For the 7 days before and after the lock up date expiration, the result on the seventh day shows that the $\mathrm{t}$-value is greater than the t-value at 5 per cent significant level. Thus, the null hypothesis which stated that there is no reaction on the abnormal return 7 days before and after the lock up expiration failed to be rejected. The findings of the study for the second period which is 14 days before and after the expiration and for the 14 days before and after expiration date, there is insignificance since the $\mathrm{t}$-value for that day is lower than $\mathrm{t}$-value at 5 per cent significance. As such, the null hypothesis which stated that abnormal return on IPOs does not react on lock up date for 14 days after expiration failed to reject. Next is the result for the third period which is 21 days before and after the lock up expiration. For the 21 days before and after the expiration, the result shows that the t-value for the $21^{\text {st }}$ day is insignificant. This finding shows that there is no reaction on price on the $21^{\text {st }}$ day before and after the expiration. For the last sub period is 30 days and shows the result before and after the lock up date expiration, the t-value on that day 
is insignificant, the null hypothesis failed to reject and therefore it can be concluded that on the 30 days before the expiration, there is no price reaction.

\subsection{Findings on Reactions Abnormal Volume 7, 14,21 and 30 Days Before and After Lock up Date}

Table 2. Reactions abnormal return 7, 14, 21 and 30 days before and after lock up date

\begin{tabular}{cccc}
\hline Sub period & AARt & S.D. & T-VALUE \\
\hline Before Lock-up Date & & & \\
\hline$(-7,0)$ & 0.165765 & 0.253308 & 0.654403 \\
\hline$(-14,0)$ & 1.47172 & 1.938252 & 1.317000 \\
\hline$(-21,0)$ & 0.5635 & 0.908387 & 1.612031 \\
\hline$(-30,0)$ & 4.308612 & 2.562796 & 1.681216 \\
\hline After Lock-up Date & & & \\
\hline$(+7,0)$ & 2.948279 & 2.383000 & 1.237213 \\
\hline$(+14,0)$ & 46.71794 & 48.830896 & 1.045228 \\
\hline$(+21,0)$ & 0.687664 & 1.170464 & 1.702086 \\
\hline$(+30,0)$ & 1.378194 & 1.102540 & 1.250017 \\
\hline
\end{tabular}

Table 2 shows the result for the first period of the reaction abnormal volume 7 days before and after the expiration date. On the seventh day before the expiration, the $t$-value for that day is greater than the $t$-value at 5 per cent significant level. Thus, the null hypothesis that stated there is no reaction from abnormal volume on lockup date for 7 days before and after expiration failed to be rejected. For the 14 days before and after the expiration, the table shows that there is no reaction of abnormal volume 14 days before the expiration. It can be proved by observing the $t$-value of the $14^{\text {th }}$ day which is greater than $\mathrm{t}$-value at the 5 per cent significant level and the null hypothesis which stated that there is no reaction from abnormal volume on IPOs 14 days before the expiration failed to be rejected. The reaction of abnormal volume 21 days before and after lock up expiration date, the $t$-value for the $21^{\text {st }}$ day before and after the expiration date is greater than the 5\% significant level. This research failed to reject the null hypothesis that there is no reaction from the abnormal volume 21 days before and after the expiration date. For the 30 days before the expiration date, the t-value of the day is greater than the t-value at the significant level which is $5 \%$. The null hypothesis which stated that the abnormal volume on IPOs not react on lock up date for 30 days before and after expiration failed to be rejected.

\section{Conclusion}

Not much has been done on IPOs and the lock up provision in Malaysia compared to other countries. This is due to the rules and regulations for public listing which require the IPO companies to lock their shares for a fixed period of 6 months. Since the period in Malaysia is fixed, the factors that could influence the lock up period can be examined. Thus, this research was conducted to see if the lock up provision can give any impact on IPOs in Malaysia. In order to identify the impact, this research was done by observing the reactions from abnormal return and abnormal volume 30 days before and after the end of the lock up period. The results of this research for 7, 14, 21 and 30 days before and after expiration of lock up date show no significant reactions on price and volume. These findings are similar as Goergen, M et.al (2010) which stated that there is no reaction from price after or before the expiration on Hong Kong market.

In Malaysia a complete explanation regarding the stock price and volume reaction at lockup expiration is not offered. Based on the discussion provided, the results for price and volume are insignificantly affected on lockup period provision for IPOs in Malaysia. The results may show for these circumstances of i) the volume will remain and the price will decrease; ii) volume will decrease and price will decrease too and iii) promoters retain percentage of shares during expiration date. For situation number i), it might show the sign of a quite good quality of performance of IPOs in stock market. Evidently, the second circumstances show decrease in price and volume of IPOs after expiration date. The scenario actually leads by demand and supply of stock. Another important evidence which supports the insignificant result is promoters retain percentage of shares during expiration date. The amounts that should be released by a company are not offered to the market during that time. The management has some hidden reason to do that. 
By looking the signaling theory, insiders of IPO firms who were previously restricted from selling their holdings have the first chance to sell large propositions of their shares. Investors will know the dates of IPO lockup expiration and numbers of shares by looking at the prospectus. Due to the scenario, the price and volume of IPOs will react during expiration date based on this theory. With regard to this theory, this study shows a different situation where signal does not contribute towards reaction on price and volume. In relation to the research, Price Pressure Theory may show the evidence that the abnormal return reaction around unlock days with no rebound in subsequent weeks. This empirical theory explains that share prices may be temporarily depressed due to a large flow of sell orders. The results for this study do not match with the price pressure theory. Field and Hanka (2001) in their past research rejected the Price Pressure hypothesis in observing the price reaction towards lock up expiration. In addition, Downward Sloping Demand Curve Theory explains the assumption during lockup expiration day that the public float of stock increases permanently as insiders unload holding. The demand curve affects positive and negative stock price reaction. This study also proves that the theory also does not support the empirical findings of this research. In the Malaysian context, the mandatory requirement by SC plays a role on reactions of price and volume of IPOs in Malaysia. SC limits the market roles in setting the price and volume by mandatory lockup for 6 months after listing. However, the ruling by SC is meant to protect the ownership of IPOs with motives of improvement incorporating images and increasing the liquidity of stock.

\section{References}

Ahmad, W., \& Jelic, R. (2014). Lockup Agreements and Survival of UK IPOs. Journal of Business Finance \& Accounting, 4l(5 \& 6), 717-742.

Arthurs, J. D., Busenitz, L. W., Hoskisson, R. E., \& Johnson, R. A. (2009). Signaling and Initial Public Offerings: The Use and Impact of The Lockup Period. Journal of Business Venturing, 24, 360-372.

Boonchuaymetta, E., \& Chuanrommanee, W. (2013). Management of The IPO Performance in Thailand. Journal of Multinational Financial Management, (23), 272-284.

Brau, J. C., Carter, D. A., Christophe, S. E., \& Key, K. G. (2004). Market Reaction to the Expiration of IPO Lockup Provisions. Managerial Finance, 30(1), 75-91.

Che-Yahya, N., Abdul-Rahim, R., \& Mohd-Rashid, R. (2015). Impact of Lock-Up Provision on Two IPO Anomalies in the Immediate Aftermarket. Capital Markets Review, 23, 25-39.

Field, L. C., \& Hanka, G. (2001, April). The Expiration of IPO Shares Lockups. The Journal of Finance, 56(2), 471-500.

Goergen, M., Mazouz, K., \& Yin, S. (2010). Price, volume and spread effects associated with the expiry of lock-in agreements: Evidence from the Hong Kong IPO market. Pacific-Basin Finance Journal, 18, 442-459.

Hussin, W. N. (2005, January). The Effects of Owners' Participation and Lockup On IPO Underpricing in Malaysia. Asian Academy of Management Journal, 10(1), 19-36.

Mackinlay, A. C. (1997, March). Event Studies in Economics and Finance. Journal of Economic Literature, 35, 13-39.

Rahim, R. A., \& Yong, O. (2010). Initial returns of Malaysian IPOs and Shari'a-compliant status. Journal of Islamic Accounting and Business Research, 1(1), 60-74.

Rashid, R. M., Abdul-Rahim, R., \& Yong, O. (2014). The Influence of Lock-Up Provisions on IPO Initial Returns: Evidence from an Emerging Market. Economic Systems, 38, 487-501.

Sapian, R. Z., Rahim, R. A., \& Yong, O. (2013). IPO Underpricing and Aftermarket Liquidity: Evidence From Malaysia. International Journal of Business and Society, 14(2), 299-318.

$\mathrm{Su}, \mathrm{D}$. ((2004). Leverage, insider ownership, and the underpricing of IPOs in China. International Financial Markets, Institutions \& Money, 14, 37-54.

Yatim, P. (2011). Underpricing And Board Structures: An Investigation of Malaysian Initial Public Offerings (IPOs). Asian Academy of Management Journal of Accounting and Finance, 7(1), 73-93.

Yong, O. (2011, June). Investor Demand, Size Effect and the Immediate Post-Listing Behavior Of Malaysian IPOS. Universiti Tun Abdul Razak E-Journal, 7(2), 23-32.

Younesi, N., Ardekani, A. M., \& Hashemijoo, M. (2012). Performance of Malaysian IPOs and Impact of Return Determinants. Journal of Business Studies Quarterly, 4(2), 140-158. 